J. Japan. Assoc. Min.

Petr. Econ. Geol.

$72,412-418,1977$.

\title{
A Rb-Sr ISOTOPIC STUDY ON THE OJIKA AND ICHINOHE GABBROIC COMPLEXES IN THE KITAKAMI MOUNTAINS, NORTHEAST JAPAN
}

\author{
Kazuya Kubo \\ Department of Earth Sciences, Fuculty of Science, Chiba University, Chrba, Japan.
}

\begin{abstract}
$\mathrm{Rb}$ and $\mathrm{Sr}$ concentrations and $\mathrm{Sr}$ isotopic compositions were analyzed for the Ojika gabbroic complex, the S-mass in the Aji islet and the Ichinohe complex in the Kitakami mountains. The initial ${ }^{87} \mathrm{Sr} /{ }^{80} \mathrm{Sr}$ ratios of $0.7045 \sim 0.7050$ for the former two is somewhat higher than that of 0.7041 for the latter.

For the Inchinohe complex, $105 \pm 30 \mathrm{~m} . \mathrm{y}$. is obtained as the whole rock isochron age, which shows well-agreement with the biotite-whole rock isochron age of $101 \sim 110 \mathrm{~m} . \mathrm{y}$. These ages indicate the age of emplacement of the Ichinohe complex.

The low initial ${ }^{87} \mathrm{Sr} /{ }^{84} \mathrm{Sr}$ ratios for these complexes indicate that incorporation of crustal materials in the original magmas is eliminated.

The $\mathrm{K} / \mathrm{Rb}$ ratios of the present district is $72 \sim 287$. These values are somewhat lower than those of some other granitic rocks in Japan.
\end{abstract}

\section{INTRODUGTION}

The Mesozoic plutonic masses of the Kitakami mountains are classified into the following three types (Kubo, 1977).

Type I: granodioritic to adamellitic masses, generally having extensive exposure, such as the Tono mass, Miyako mass and Senmaya mass.

Type II: gabbroic masses with various amounts of quartz dioritic rock, such as the Ojika mass, Tenjinmori mass and Orikabe mass. The masses of this type are characterized by low $\mathrm{K}$ compared with the masses of Type III, though monzonitic rock is sometimes associated with them.

Type III: gabbroic masses, characterized by higher $\mathrm{K}$, with various amounts of adamellitic and syenitic rocks, such as the Ichinohe mass and Himekami mass.

To elucidate the origins and mutual relationships of these three types of the masses, the geological and petrological characters of several plutonic masses have been investigated (Kubo, 1976, 1977). In the present paper, will be reported the Sr isotopic ratios of the Ojika mass and its satellitic mass belonging to Type II, and of the Ichinohe mass belonging to Type III. With respect to the $\mathrm{Sr}$ isotopic features of the masses belonging to Type $I$, the data for the Tono and Kesengawa masses, Miyako mass and Taro mass have been reported by Shibata (1974) and Shibata et al. (1977), respectively.

\section{Geological Setting}

The Ojika gabbroic complex is exposed at the central part of the Ojika Peninsula, intruding the Mesozoic formation of the Ojika group. It is composed of seven rock types, such as clinopyroxenite, porphyritic 
clinopyroxene gabbro, olivine two pyroxene gabbro, clinopyroxene hornblende gabbro, two pyroxene gabbro, pyroxene hornblende diorite and quartz diorite, in the order of intrusion. The petrology of the complex has recently been reported by Igi et al. (1974) and Kubo (1977).

The S-mass is one of the satellitic masses of the Ojika gabbroic complex, being exposed at the southern coast of the $A j i$ islet to the south of the Ojika Peninsula. It is composed of six rock types, such as granodiorite, medium-grained quartz gabbro, fine-grained quartz gabbro, quartz diorite, medium-grained monzonitic quartz diorite and fine-grained monzonitic quartz diorite. The petrography of the mass has been reported by Kubo (1976).

The Ichinohe complex is outcropping in the Paleozoic formation at Ichinohe, near the northern end of Iwate Prefecture. It is composed of three masses such as olivine bitotite clinopyroxene alkali gabbro group, biotite hornblende alkali gabbro group and quartz syenite group. Petrology of this complex has been reported by Onuki and Tiba (1964).

\section{Analytigal Procedures}

Whole rock samples used in the present study were prepared from $1 \sim 3 \mathrm{~kg}$ rock specimens. Biotite separation was carried out tapping the rock-powder within a glassbeaker.

$\mathrm{Rb}$ and $\mathrm{Sr}$ concentrations were determined by isotope dilution method using ${ }^{87} \mathrm{Sr}$ and ${ }^{84} \mathrm{Sr}$ spikes.

Isotope analyses were made on the JEOL-05 RB mass spectrometer with a $90^{\circ}-30 \mathrm{~cm}$ radius analyzer. Triple filaments were used amd nsaples were loaded on the side filaments as $\mathrm{Rb}_{2} \mathrm{SO}_{4}$ or $\mathrm{Sr}\left(\mathrm{NO}_{3}\right)_{2}$.
Ion currents were detected with an electron multiplier, output of which was amplified by a vibrating reed electrometer, recorded on a digital voltimeter and punched on paper tape.

All. ${ }^{87} \mathrm{Sr} /{ }^{86} \mathrm{Sr}$ ratios analyzed were normalized to ${ }^{87 \mathrm{Sr}}{ }^{86 \mathrm{Sr}}=0.1194$ and adjusted ${ }^{87} \mathrm{Sr} /{ }^{86} \mathrm{Sr}=0.7080$ for Eimer and Amend Sr standard.

${ }^{87} \mathrm{Sr} /{ }^{86} \mathrm{Sr}$ ratios listed in Table 1 are mean values of $20 \sim 30$ peak sets, of which twice of the standard deviation is $0.0006 \sim$ 0.0012 .

The analytical uncertainty in $\mathrm{Rb}$ and $\mathrm{Sr}$ concentrations is considered to be less than $3 \%$. For several samples, $\mathrm{Rb}$ and $\mathrm{Sr}$ concentrations were determined by $\mathrm{X}$-ray fiuorescence analysis or $\gamma$-ray spectrometry analysis, so that the uncertainty for the concentrations is somewhat larger, being however less than $10 \%$. ${ }^{\text {"r }} \mathrm{Rb}$ decay constant used is $1.39 \times 10^{-11} / \mathrm{y}$.

\section{Results AND Discussion}

All the Rb-Sr data analyzed are listed in Table $\mathbf{1}$ and the whole rock data are displayed in ${ }^{87} \mathrm{Sr} /{ }^{86} \mathrm{Sr}-{ }^{87} \mathrm{Rb} /{ }^{86} \mathrm{Sr}$ isochron diagram in Figure 1.

\section{The Ojika gabbroic complex}

Six samples taken from the main rock types were analyzed. $\mathrm{Rb}$ content of each rock type is low, reflecting the character poor in $\mathrm{K}$ content. ${ }^{87} \mathrm{Rb} /{ }^{86} \mathrm{Sr}$ ratios are not so different that meaningful isochron is not defined. The K-Ar age of biotite+hornblende in quartz diorite of the complex was determined by Kawano and Ueda (1964), giving $120 \mathrm{~m} . \mathrm{y}$. Supposing that this age being that of the emplacement of the complex, initial ${ }^{87} \mathrm{Sr} /{ }^{86} \mathrm{Sr}$ ratio of the complex is considered to be $0.7045 \sim 0.7050$. 
Table 1. Analytical data.

\begin{tabular}{|c|c|c|c|c|c|c|c|}
\hline No. & Sp. No. & $\begin{array}{c}K \\
\left(\frac{a}{b}\right)\end{array}$ & $\begin{array}{c}\mathrm{Rb} \\
(\mathrm{ppm})\end{array}$ & $\begin{array}{c}\mathrm{Sr} \\
(\mathrm{ppm})\end{array}$ & $\mathrm{K} / \mathrm{Rb}$ & ${ }^{8} \mathrm{~Pb} /{ }^{86} \mathrm{Sr}$ & ${ }^{87} \mathrm{Sr} /{ }^{86} \mathrm{Sr}$ \\
\hline 1 & 74041901 & 0.12 & $6 *$ & $495^{*}$ & 200 & $0.037^{*}$ & 0.70488 \\
\hline 2 & 74121607 & 0.07 & 7.8 & 560.0 & 90 & 0.0402 & 0.70406 \\
\hline 3 & 73072309 & 0.07 & tr. & $552 *$ & & & 0.70431 \\
\hline 4 & 73072608 & 0.24 & 12.9 & 513.6 & 186 & 0.0729 & 0.70528 \\
\hline 5 & 75110301 & 0.17 & 22.0 & 602.0 & 77 & 0.1058 & 0.70506 \\
\hline 6 & 533 & 0.76 & $21^{*}$ & $479 *$ & 362 & $0.126 *$ & 0.70483 \\
\hline 7 & 74061703 & 0.64 & $23^{* *}$ & 631 ** & 278 & $0.106 * *$ & 0.70477 \\
\hline 8 & 74012913 & 1.05 & $56 * *$ & $593^{* *}$ & 188 & $0.273 * *$ & 0.70514 \\
\hline 9 & 74012910 & 2.00 & $97^{* *}$ & $625 *$ & 206 & $0.449 * *$ & 0.70529 \\
\hline 10 & 74012911 & 1.55 & $86 * *$ & $510 * *$ & 180 & 0.488 ** & 0.70529 \\
\hline 11 & K 334 & 1.73 & $71 *$ & $419 *$ & 244 & $0.489 *$ & 0.70496 \\
\hline 12 & K 335 & 4.31 & $182^{*}$ & $764^{\star}$ & 237 & 0.689 * & 0.70513 \\
\hline 13 & K 337 & 0.34 & 46.7 & 87.7 & 73 & 1.5486 & 0.70634 \\
\hline 14 & 75111001 & 2.74 & 107.6 & 1333.5 & 255 & 0.2337 & 0.70432 \\
\hline 15 & 75111101 & 3.55 & 123.9 & 960.9 & 287 & 0.3735 & 0.70472 \\
\hline \multicolumn{2}{|c|}{$\begin{array}{l}\text { Biotite } \\
\text { B- } 75111001\end{array}$} & & 415.8 & 22.3 & & 53.8947 & 0.78574 \\
\hline
\end{tabular}

No. 1 6: The Ojika gabbroic complex.

1: Porphyritic clinopyroxene gabbro. 2: Olivine two pyroxene gabbro. 3: Two pyroxene gabbro. 4: Pyroxene hornblende điorite. 5: Quartz diorite. 6: Porphyritic clinopyroxene gabbro intruded by quartz diorite.

No. $7 \sim 10$ : The S-mass.

7: Medium-grained quartz gabbro. 8: Quartz diorite. 9: Medium-grained monzonitic quartz diorite. 10: Fine-grained monzonitic quartz diorite.

No. 11 15: The Ichinohe complex.

11: Alkali gabbro. 12: Quartz syenite. 13: Olivine clinopyroxenite. 14: Alkali gabbro.

15: Hornblende alkali gabbro.

Biotite: separated from the rock sample No. 14

* X-ray fluorescence analysis. ** $\gamma$-ray spectrometry analysis.

\section{The S-mass}

Four samples from the main rock types were analyzed. $\mathrm{Rb}$ content of each rock type is somewhat higher than those in the Ojika gabbroic complex, though the variation of ${ }^{87} \mathrm{Rb} /{ }^{80} \mathrm{Sr}$ ratio is not so much as defining the isochron. The differentiation of the S-mass is mainly controlled by the mechanical behavior of crystals in the melt during emplacement (Kubo, 1976), and calcic plagioclase as well as K-feldspar is enriched in the derivatives at later stage of differentia- tion. This may be the reason why $\mathrm{Rb} / \mathrm{Sr}$ ratio is not so high in spite of relatively higher content of K-feldspar.

The $\mathrm{Rb}-\mathrm{Sr}$ isotopic data mentioned above are in accordance with the idea that the S-mass and Ojika gabbroic complex were derived from a common original magma, assuming that both masses were emplaced in almost same age.

\section{The Ichinohe complex}

Five whole-rock samples and one biotite 


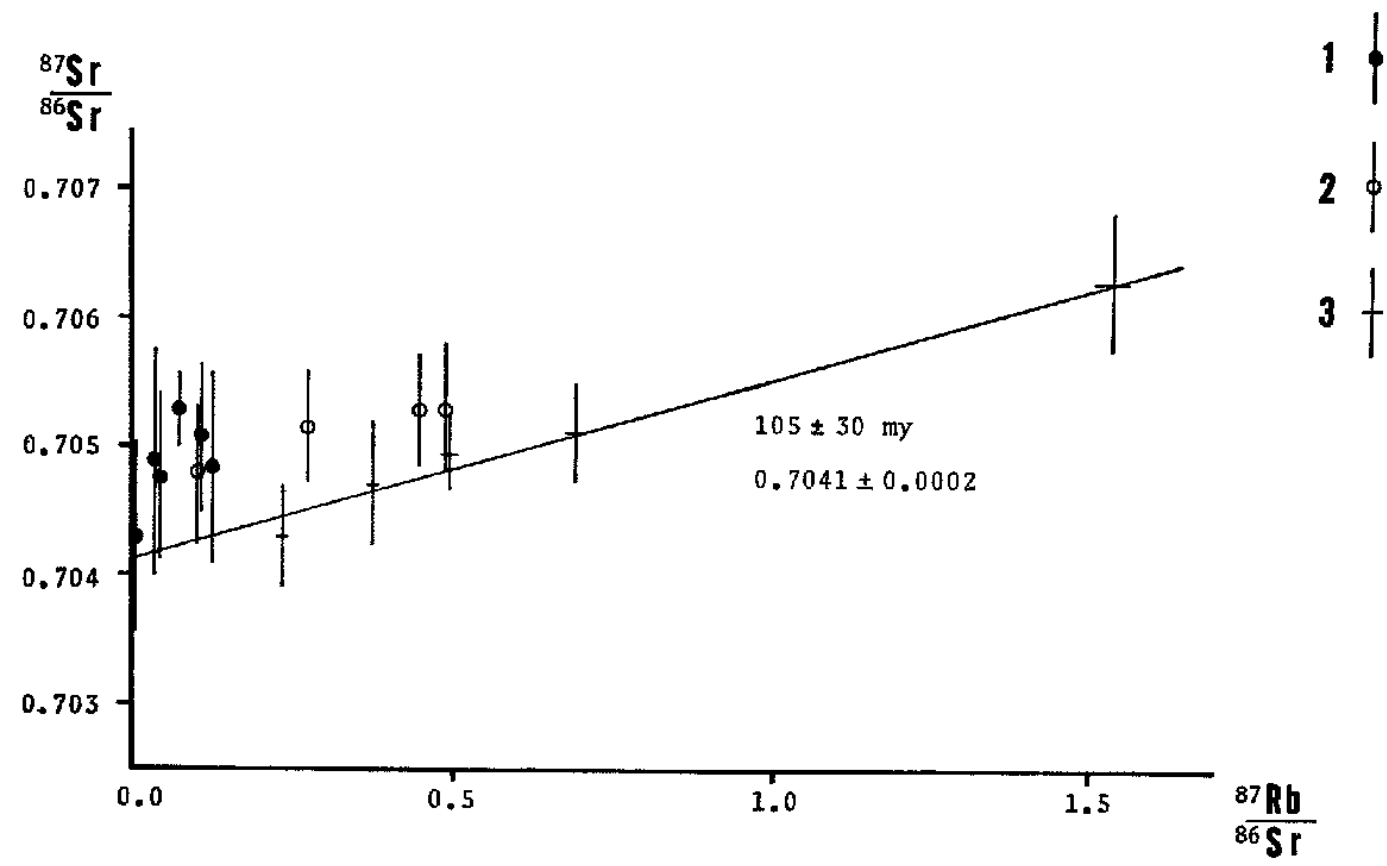

Fig. 1. Whole rock isochron diagram.

1: The Ojika gabbroic complex. 2: The S-mass. 3: The Ichinohe complex.

sample were analyzed. The data for wholerock samples define an isochron of $105 \pm 30$ m.y. with an initial ${ }^{87} \mathrm{Sr} /{ }^{86} \mathrm{Sr}$ ratio of $0.7041 \pm$ 0.0002 . And also, the age calculated from the biotite-whole rock isochron is $101 \sim 110$ m.y. These ages are in agreement with the $\mathrm{K}$-Ar ages of $106 \sim 116 \mathrm{~m} . \mathrm{y}$. for microcline and biotite determined by Kawano and Ueda (1964). Therefore, these ages are considered to indicate the age of the emplacement of Ichinohe complex. In this case, the consolidation of the complex after emplacement must have proceeded rapidly.

Onuki and Tiba (1964) considered that the Ichinohe complex was formed by successive intrusion of magmas derived and uprison from a common magma reservoir at certain deeper level. If it was the case, the above data indicate that all the processes, the differentiation of magma at depth and the emplacement and consolida- tion of the complex, proceeded in a relatively short span of time.

Initial ${ }^{87} \mathrm{Sr} /{ }^{86} \mathrm{Sr}$ ratios

The initial ${ }^{87} \mathrm{Sr} /{ }^{86} \mathrm{Sr}$ ratios of the Ojika gabbroic complex and S-mass are somewhat higher than that of the Ichinohe complex, though the difference is smaller than 0.001 . If this difference is meaningful, it would be ascribed to the slight difference of the source materials from which both complexes were derived. Because it is difficult to derive the both magma types from a common source, one being more enriched in $\mathrm{Rb}$ and lower in ${ }^{87} \mathrm{Sr} /{ }^{86} \mathrm{Sr}$ ratio and the other being poorer in $\mathrm{Rb}$ and higher in ${ }^{87} \mathrm{Sr} /{ }^{86} \mathrm{Sr}$ ratio.

It may be admitted, however, another possibility exists for the genetical relation of both types of magma. Namely, the initial ${ }^{87} \mathrm{Sr} /{ }^{86} \mathrm{Sr}$ ratio may be a function of the duration from the time of formation of 
original (undifferentiated) magma to the time of differentiation into magmas represeting each rock type. Therefore, if the above duration is somewhat longer for the case of the Ojika gabbroic complex than that of the Ichinohe complex, both complexes could be interpreted as the derivatives from a common source.

Some of the plutonic masses belonging to Type I have been isotopically analyzed. The Tono and Kesengawa granites reproted by Shibata (1974) have the initial ${ }^{87} \mathrm{Sr} /{ }^{86} \mathrm{Sr}$ ratio of $0.7043 \pm 0.0004$. The Miyako and Taro granites were also analyzed (Shibata et al., 1977), the initial ${ }^{87} \mathrm{Sr} /{ }^{86} \mathrm{Sr}$ ratio of the former being $0.70378 \pm 0.00015$.

Thus, it may be concluded that the three types of plutonic masses in the Kitakami mountains are fairly similar in their initial ${ }^{87} \mathrm{Sr} /{ }^{86} \mathrm{Sr}$ ratios, ranging from 0.7035 to 0.7050 , the possibility of incorporation of crustal materials in the original magma being eliminated.

Recently, Shuto (1974) has proposed the division of $\mathrm{L}$ zone and $\mathrm{H}$ zone of the Cenozoic acidic volcanic rocks in Japan based on their initial ${ }^{87} \mathrm{Sr} /{ }^{86} \mathrm{Sr}$ ratios, and Shuto and Kagami (1975) have shown that the zonal distribution mentioned above might be adoptable also to the Mesozoic granites. The present data are in harmony with their results.

\section{$K / R b$ ratios}

All the present data are plotted in K$\mathrm{Rb}$ diagram (Fig. 2). They are in the Main trend of Shaw (1968), and show the K/Rb ratios ranging from 72 to 287 (except for metamorphosed rock sample). The data are also plotted in $\mathrm{K} / \mathrm{Rb}-\mathrm{K}$ diagram (Fig. 3). As shown in this diagram, the data for Ichinohe complex are plotted in the area of alkali basalts (Beswick, 1976) and those for the Ojika gabboric complex have some-

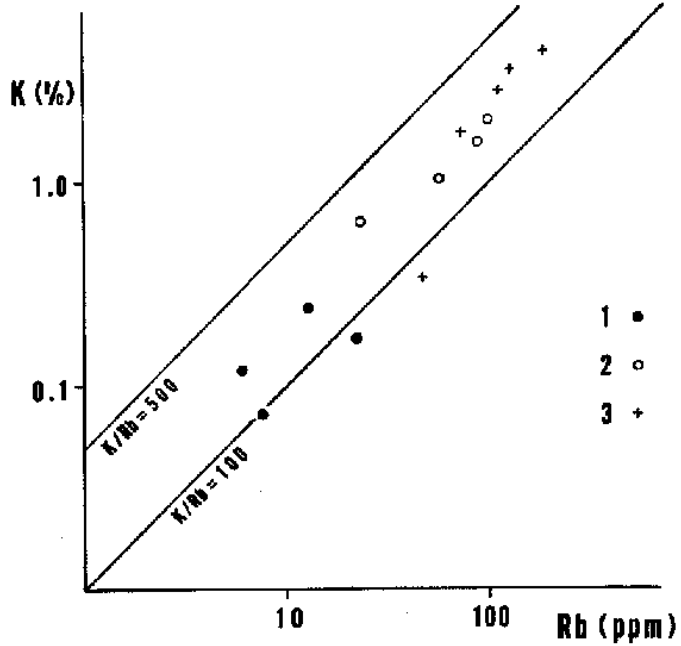

Fig. 2. Plots of $K$ versus $R b$ for the rocks, 1: Ojika gabbroic complex, 2: Smass and 3: Ichinohe complex.

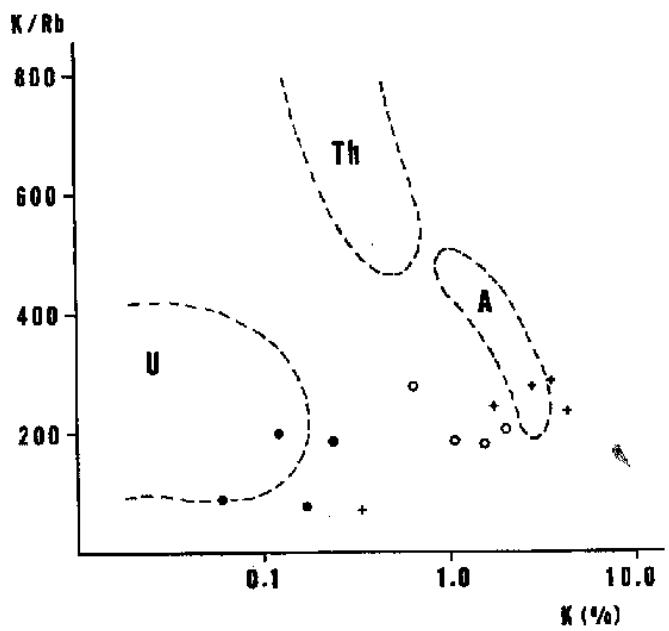

Fig. 3. Plots of $K / R b$ versus $K$. Symbols are the same as Figure 2. Th, $A$ and $U$ are the fields for oceanic tholetite, alkali basalt and ultramafics, respectively (Beswick, 1976).

what wider range of variation. Systematic change of $K / R b$ ratios with the differentiation of each complex is not recognized.

The $\mathrm{K} / \mathrm{Rb}$ ratios of granitic rocks in Japan have been reported in recent years (Ishizaka, 1971; Ishizaka \& Yanagi, 1977; 
Kanaya \& Ishihara, 1977). The $\mathrm{K} / \mathrm{Rb}$ ratios of Central Ryoke granites are ranging from 100 to 400 . The ratios of Ibaragi granitic complex range from 150 to 250 and those of Tanzawa plutonic rocks range from 541 to 630 . Compared with these data, the $\mathrm{K} / \mathrm{Rb}$ ratios of the present district is somewhat low.

\section{AGKNOWLEDGEMENT}

The author wishes to express his thanks to Dr. M. Gorai of Tokyo University of Education for constant guidance in the course of the work and critical reading of the manuscript and to Dr. K. Kanehira of Chiba University for critical reading of the manuscript.

The author is also indebted to Dr. K. Kagami of Institute for Thermal Spring Research, Okayama University and Dr. K. Shuto of Tokyo University of Education, for their helpful suggestions and encouragement.

Drs. T. Shirahase, K. Shibata and T. Tanaka, of Geological Survey of Japan, gave him kind guidance and helped for using the mass spectrometer. Messrs. $H$. Kanaya and H. Endo, both of Geological Survey of Japan, kindly measured the $\mathrm{Sr}$ and $\mathrm{Rb}$ contents of several specimens. The author expresses his sincere thanks to them.

\section{REFERENGES}

Beswick, A.E. (1976), $\mathrm{K}$ and $\mathrm{Rb}$ relations in basalts and other mantle derived materials. Is phlogopite the key ? Geochim. Cosmochim. Acta., 40, 1167-1183.

Igi, S., Katada, M., Takizawa, F. and Abe, T. (1974), Gabboric complexes in the Ojika pen- insula and Kasagai islet, Miyagi Prefecture, Japan. Jour. Geol., Soc. Japan, 80, 107-114.

Ishizaka, K. (1971), A Rb-Sr isotopic study of the Ibaragi granitic complex, Osaka, Japan. Jowr. Geol. Soc. Japan, 77, 731-740.

- and Yanagi, T. (1977), K, Rb and Sr abundances and $\mathrm{Sr}$ isotopic composition of the Tanzawa granitic and associated gabbroic rocks, Japan: Low-potash island arc plutonic complex. Earth Planet. Sci. Letters, 33, 345352.

Kanaya, H. and Ishihara, S. (1977), K/Rb ratios of Ryoke granities, central Japan. Abst. 84th Annual Meet. Geol. Soc. Japan, 52. (in Japanese)

Kawano, Y. and Ueda, Y. (1965), K-Ar dating on the igneous rocks in Japan (II) - Grantic rocks in Kitakami massif - . Sci. Rept. Tohoku Univ. Ser. II, 9, 199-215.

Kubo, K. (1976), Layered structure in the basic intrusive mass in the $\mathrm{Aji}$ islet, Miyagi Prefecture, northeast Japan. Jour. Geol. Soc. Japan, 82, 423-440.

(1977), Petrological study on the Ojika. gabbroic complex, Kitakami mountains, northeast Japan. Jowr. Geol. Soc. Japan, (in press).

Onuki, H. and Tiba, T. (1964), Petrochemistry of the Ichinohe alkali plutonic complex, Kitakami mountainland, northern Japan. Sci. Rept. Tohoku Univ., Ser. [1, 9, 123-154.

Shaw, D.M. (1968), A review of K-Rb fractionation trend by covariance analysis. Geochim. Cosmochim. Acta, 32, 573-601.

Shibata, K. (1974), Rb-Sr geochronology of the Hikami granite, Kitakami mountains, Japan. Geochem. Jour., 8, 193-207.

- Yanagi, T. and Famamoto, R. (1977), Isotopic ages of the Mesozoic granites and volcanics in the Kitakami mountains. (Abstract) J. Japan. Assoc. Min. Petr. Econ. Geol., 72, 119. (in Japanese)

Shuto, K. (1974), The strontium isotopic study of the Tertiary acid volcanic rocks from the southern part of northeast Japan. Sci. Rept. Tokyo Kyoiku Daigaku, Section C, 12, no. 116, 75-140.

- and Kagami, H. (1975), Regional variations in the $\mathrm{Sr}$ isotopic composition in the Cenozoic tholeitic calc-alkali volcanic rocks from the Intra- and Circum-Pacific Regions. Earth Sci. (Chikyu Kagahu), 29, 75-86. 


\title{
北上山地，牡庵及びー戸斑れい岩体の Rb-Sr 同位体による研究
}

\author{
久保和也
}

北上山地，特鹿岩体と，その近傍の同一マグマ起源と予想される網地島 S岩体加ら計 10 個，一戸岩体汃ら 5 個の全岩試料及び後者中の黑雲母の試料 1 個の Sr 同位体を測定した。

一戸岩体の黒雲目一全岩年代 $(101 \sim 110 \mathrm{~m}$. y.) と全岩アイソクロン年代 $(105 \pm 30 \mathrm{~m} . \mathrm{y}$.$) とは良い一致走示$ す。てれらの年代崠本岩体の K-Ar 年代とも一致しており，従って岩体の进入の年代を示していると考えられる。 この場合、マグマの分化から迸入固結までの時間估短かかった。

牡鹿岩体の試料は $\mathrm{Rb}$ 亿元しく，全岩アイソクロンをひく事ができないししかしながら，石英閧緑岩の K-Ar 年代 (120 m. y.) を岩体の进入年代と考元ると，本岩体学形成したマグマは进入時に $0.7045 \sim 0.7050$ の ${ }^{87} \mathrm{Sr} /$ ${ }^{86} \mathrm{Sr}$ 比を有していた事になる。この值は一戸岩体の值(0.7041)に比べてかずかながら高い。との差は起源物暂 の違いによるものであるかも知れないが，マグマの発生加ら分化までの睦間の差によっても説明は可能である。 いずれにしてるとれらの值は，両岩体のマグマの形成に地款物質が全んど寄与していない事を示す。

両岩体の $\mathrm{K} / \mathrm{Rb}$ 比注 72〜287 で，日本の他の花阙岩体の報告例と比べるとやや低い值である。 